Abstracta Iranica Abstracta Iranica

Revue bibliographique pour le domaine irano-aryen

Volume 26 | 2005

Comptes rendus des publications de 2003

\title{
Turkestan and the Fate of the Russian Empire. Londres, Routledge-Curzon, 2003, 240 p., bibliographie, index.
}

\section{Stéphane A. Dudoignon}

\section{(2) OpenEdition}

Journals

Édition électronique

URL : http://journals.openedition.org/abstractairanica/2852

DOI : 10.4000/abstractairanica.2852

ISSN : 1961-960X

Éditeur :

CNRS (UMR 7528 Mondes iraniens et indiens), Éditions de l'IFRI

Édition imprimée

Date de publication : 15 mai 2005

ISSN : 0240-8910

Référence électronique

Stéphane A. Dudoignon, «Turkestan and the Fate of the Russian Empire. Londres, Routledge-Curzon, 2003, 240 p., bibliographie, index. », Abstracta Iranica [En ligne], Volume 26 | 2005, document 253, mis en ligne le 08 décembre 2005, consulté le 25 septembre 2020. URL : http://journals.openedition.org/ abstractairanica/2852 ; DOI : https://doi.org/10.4000/abstractairanica.2852

Ce document a été généré automatiquement le 25 septembre 2020.

Tous droits réservés 


\title{
Turkestan and the Fate of the Russian Empire. Londres, Routledge-Curzon, 2003, 240 p., bibliographie, index.
}

\author{
Stéphane A. Dudoignon
}

Spécialiste reconnu de l'histoire des politiques russes de domination de l'Asie Centrale, l'A. a animé le Borderland Research Group, qui a puissamment contribué au renouveau actuel des études sur le colonialisme russe (cf. D. Brower \& E. Lazzerini, eds., Russia's Orient. Imperial Borderlands and Peoples, Bloomington, IN : Indiana University Press, 1997). D.B. propose ici un recueil d'articles de synthèse sur l'évolution du «discours colonial » en Russie, à travers les débats idéologiques et décisions stratégiques qui ont successivement orienté la définition des relations entre les populations du Turkestan et leurs conquérants entre 1860 et 1920 . Même si l'ouvrage n'est pas à proprement parler une monographie, l'absence de discussion de quelques contributions majeures sur la question (outre la périodisation esquissée par H. Carrère d'Encausse, Réforme et révolution chez les musulmans de l'Empire russe, Paris, FNSP, 1966, on mentionnera une récente tentative de typologie régionale dans S. G. Agadžanov, ed., Nacional'nye okrainy Rossijskoj imperii. Stanovlenie i razvitie sistemy upravlenija, Moscou, Slavjanskij dialog, 1997) amène l'A. à un certain nombre de redites. L'idée centrale du recueil est la constante d'une opposition entre " conservateurs ", partisans de la manière autoritaire, et "réformistes", soucieux d'une meilleure intégration politique des populations conquises dans l'Empire russe. Nourri de longues recherches dans les Archives centrales d'État d'Ouzbékistan, les Archives d'histoire militaire de la Fédération de Russie à Moscou et les Archives historiques d'État de Saint-Pétersbourg, l'ouvrage présente, notamment, le grand intérêt de mettre en relief des logiques de la colonisation agricole russe de l'Asie Centrale, et son poids dans les débats du tournant $\mathrm{du} 20^{\mathrm{e}} \mathrm{s}$. Il restitue également la grande porosité entre tendances conservatrices et réformistes de l'administration coloniale, s'efforçant d'élucider les mobiles politiques des uns et des autres, et trace d'intéressantes perspectives sur les continuités de la politique des nationalités en Asie Centrale russe, entre la veille de la Première Guerre mondiale et le début de la période soviétique. Une synthèse stimulante et qui échappe 
totalement au manichéisme de rigueur dans une grande majorité d'études sur cette thématique.

INDEX

Thèmes : 4.2.2. Asie centrale

\section{AUTEURS}

STÉPHANE A. DUDOIGNON

Université Marc Bloch - Strasbourg 